\title{
THE USE OF INCENTIVES IN FOSTERING GREEN BUILDINGS
}

\author{
Selin GÜNDEŞ*, Şiar Umut YILDIRIM**
}

Received: 19.03.2015; Final Text: 01.10.2015

Keywords: Building sector; green buildings; incentives; sustainable buildings; local governments.

\footnotetext{
* Department of Architecture, Mimar Sinan Fine Arts University, İstanbul, TURKEY.

** İstanbul, TURKEY.
}

\section{INTRODUCTION}

Although greening of the built environment has been on the agenda of many governments, the progress has been reported to be slow mainly due to fear of higher costs, resistance to new technologies, lack of client demand and cooperation (Gluch et al., 2013; Hakkinen and Belloni, 2011; Sayce et al., 2007; United Nations Environment Programme and Sustainable Building and Construction Initiative UNEP and SBCI, 2009). One common theme of the increasing number of research in this area is that it is social and psychological barriers rather than technological that hinders the development of a sustainable built environment (Gluch et al.,2013; Hoffman and Henn, 2008). Thus, a better understanding of stakeholder behaviour and concerns is pointed out to be one of the key factors for the effectiveness of policies and efforts to make green buildings a 'mainstream' standart practice (Bartlett and Howard, 2000; Cole, 2011; du Plessis and Cole, 2011; Feige et al., 2011; Kaatz et al., 2005; Kaatz et al., 2006; Wallbaum et al.,2010).

Among various stakeholder groups involved in the built environment, the encouragement of developers for building green raise several particular concerns that can not be easily resolved merely through increased awareness. One problem that stands out in many studies is the fear of additional costs or the affordability barrier faced by developers and clients (Bon and Hutchinson, 2000; Circo, 2008; Osmani and O'Reilly, 2009; Pitt et al., 2009; Sayce et al., 2007; Zhang et al., 2011). Despite the perceived additional costs, research reveals that green buildings have several financial advantages in the long term compared to non-green buildings, mainly due to energy and water savings provided during operational phase (Bartlett and Howard, 2000). However, as these benefits are mostly accrued at the post-production period, there is no direct reason to focus on sustainability issues on the side of developers, who mainly concentrate on the short term profitability of investments (Bordass, 2000; Y1ldırım, 2014). 
Recent research have questioned the factors that could provide a motivation for developers in building green such as increased value (Royal Institute of Chartered Surveyors (RICS), 2005), enhanced brand recognition and reputation (Carter, 2006; Gluch et al., 2013; Pett et al., 2004) and corporate social responsibility considerations (Ang and Wilkinson, 2008; Lützkendorf et al., 2011; Osmani and O'Reilly, 2009). Although a promising factor among all appears to be the value enhancement in terms of yields and rents, lack of satisfactory empirical evidence for increased values (Sayce et al., 2007) creates yet another obstacle for businesses. Miller, Spivey and Florance (2008), Ellison et al. (2007), Wiley et al. (2010) and Fuerst and McAllister (2011) are among the few studies that have focused on the effect of building environmental performance on prices.

Thus, the fear of higher capital costs coupled with the tendency of developers to focus on the initial costs of development projects rather than the lifecycle costs still remains as one of the main challenges for green building markets (Antoniades, 2011; Bordass, 2000; Sayce et al. 2007). This important barrier facing the development of green buildings has triggered many governments to revise their regulations in particular about construction and tax. As a result, several mechanisms were put into action in order to encourage developers for building green mainly through the provision of benefits at the initial phases of green building projects. In this context, economic incentives emerged as powerful instruments in changing the behaviour of developers. Incentives are considered to be valuable tools in generating interest, in creating a motive for the adoption of green building practices over conventional practices and in eliminating knowledge gaps (UNEP SBCI, 2009; US EPA Region 5 Nemw and Delta Institute, 2008).

However, much of the experience with environmental policies comes from developed countries and this experience is not "readily transferable" to developing countries for a number of reasons (Panayotou, 1994). The first dimension of the intransferability problem arises from the strong connections between economic and environmental policies. Conventional economic theory suggests that the improvement of environmental performance through policies may negatively affect economic growth (Jaffee et al., 1995). Thus, developing countries, with very different prevailing conditions and concerns, relegate environmental problems to a secondary concern. Furthermore, despite recent efforts to share knowledge gained from the experiences of developed countries with environmental policies, these experiences still remain largely undocumented and this negatively affects their transfer.

Given the importance of economic incentives in promoting the development of green building markets, this research aims to fill the information gap concerning the adaptability of economic incentives to the developing world by taking Turkey as a case. Turkey is a rapidly developing country which is in the primary phase of the green building movement and prerequisites for the development of the green building market have still not been generated. However, the strong economic growth brings along an increased energy demand and consequently energy policies emphasize the provision of energy at lower costs, with high continuity and less dependency on foreign resources. In this concept, there are also ongoing efforts to disseminate the concept of sustainable construction; in particular low energy houses through programs coordinated by governments, financial institutions and non governmental 
organizations. One of the first attempts was the regulation called 'The Energy Performance of Buildings' which mandates energy identity document as of 2017. The research is timely also due to the opportunities offered by the Urban Renewal Law approved in 2012. The massive Urban Renewal Programme aims to develop a safe built environment by demolishing the illegal and unsafe buildings across the Country and rebuilding earthquake resistant structures. Approximately one third of the $20 \mathrm{~m}$ housing stock is planned to be regenerated by the Programme (Oxford Business Group, 2012). Thus, the Program provides significant opportunities for the development of a greener environment.

The research questions addressed in this study include

- how do key actors evaluate the applicability of green building incentive models in terms of particular requirements, difficulties and opportunities?

- given the additional resource requirements of some incentive models, in what ways and to what extent can local governments can create and/or allocate resources for the effective implementation of these models?

Although this article focuses on the implementation of incentive models in one specific country, other countries with similar prevailing economic and societal concerns may also benefit from the findings. This is because; apart from stakeholder behaviour, "local context" is often emphasized to be another crucial aspect in the effective implementation of these instruments (Feige et al., 2011). The study by UNEP and SBCI (2007) further specifies the constituent parts of the local context as the structure of the local market, the culture, the local policy framework and timing.

\section{GREEN BUILDING INCENTIVES}

Recent research on sustainable construction have shown that lack of incentives is one of the most important factors hindering the adoption of sustainable development (Ang and Wilkinson, 2008; Gluch et al., 2013). In particular, many studies emphasize the role of fiscal incentives in overcoming the barrier of 'affordability' and thus in driving sustainable construction (Pitt et al, 2009; Sodagar and Fieldson, 2008). However, interestingly the availability of data on the effects of policy instruments is very limited (Meijer et al., 2009).

The most common classification for green building incentives are the structural (or non-monetary or intangible) and financial (or monetary, tangible, fiscal) incentives (US Green Building Council USGBC, 2010). While both groups aim to increase the attractiveness of building green for developers, they are distinct in the way they act in doing so. The most common instruments in the first category include expedited review/permitting and density/height bonuses and their primary aim is to attract developers by the provision of time and money savings for green developments. Structural incentives are an appropriate option for municipalities that encounter financial difficulties, as they can be put into action with low or no costs. On the other hand, there are some potential problems during the implementation stage such as lack of a specialized staff and social impacts with higher density.

Financial incentives on the other hand, include tax credits/abatements, fee reduction/waivers and awards. The aim of the second category is 
to compensate the additional costs of certain sustainability measures associated with green buildings. The remaining part of this section provides a brief explanation of the studies focusing on specific incentive mechanisms and their implementation.

\section{Expedited Review/ Permitting}

A prolonged part of the development phase is generated by building permitting and plan review (Pippin,2009). Speeding up the processes associated with permits and reviews is an attractive opportunity for developers as reduced overall duration and early project completion provide significant benefits such as rapid complete sellings/tenancies, an opportunity to focus on the next project earlier and indirect or provisional cost savings. Local governments may also benefit from increased tax gains as more projects will be completed quickly.

In order to qualify for expedited permits and reviews, applicants are required to demonstrate congruency with a particular green building certification system. The reductions in permit durations offered by local governments vary depending on the level of certification; with shorter permits for eligibility to higher levels of certification such as the Leadership in Energy and Environmental Design (LEED) Gold or Platinum.

Several problems experienced in the implementation of expedited reviews and permitting are recorded in literature. Retzlaff (2009) points out that the necessity of qualified staff to ensure compatibility with program requirements is an important challenge during application. Circo (2009) states that these incentives are eloquent for developers only if the gains from shortened durations are enough to compensate for the extra costs of sustainable design and construction.

\section{Density and Height Bonuses}

Density and Height Bonuses provided for green building developers aim to increase revenues through additional unit permits in the form of either the Floor/Area Ratio (FAR) or height bonuses. The benefits for developers can be accrued both in the short-term by the sale of additional units and in the long-term by higher rent gains (USGBC, 2010). For example in the County of Arlington (US) FAR bonuses offered for green buildings range from 0.15 for LEED Certified, to 0.25 for LEED Silver and 0.35 for LEED Gold or Platinum certifications. Besides density bonuses, the County also offers additional height up to three stories for LEED Silver or higher rated projects under the Arlington County Incentive Program. Similar to expedited review/permitting process, density bonus also requires that the applicant demonstrates eligibility for certification systems.

However, several problems encountered in the implementation of density and height bonuses are reported in literature. First, as developers apply for bonuses in the pre construction period, there is no guarantee that the constructed product will comply with the selected green building standard. In this regard, proof of compliance emerges as a considerable problem. Several sanction models are developed for projects which, in later stages are not able to achieve the desired certification level. For example, developers may be required to post a bond or letter of credit during the FAR bonus application and in case the completed development is not able to achieve the certification, the bond or credit amount defaults to the local government (Pippin, 2009). Some local governments (e.g. Seattle) have developed a penalty system where the amount of penalty is 
dependent on the missing credits for earning the desired certificate and the value of construction. Second, although density and height bonuses fall under the structural incentive category, still the necessity of extra staff may translate into additional costs for local governments. In some cases, the assessment procedure is outsourced to the private sector (e.g. San Fransisco). Third, the increased need for physical infrastructure (e.g. roads, public facilities etc.) and social costs of greater intensity growth may further complicate the implementation of density and height bonus system. Thus the bonus system is not applicable in all regions, in particular in the historical districts. In this concept, Retzlaff (2009) emphasize the challenges associated with the implementation of the bonus sytem in historical districts with strict zoning restrictions.

\section{Tax abatements and credits}

Tax abatements and credits aim to stimulate developers for building green through reduced and in some cases through an exemption from taxes for a specified period of time (UCGBC, 2010). In other words, tax credits are used as a tool for faster amortization than the usual interval and developers can in this way increase their revenues. In practice, flexibility is also provided in cases where tax liability in a year is not sufficient to use up the total credit (Pippin, 2009).

Circo (2009) suggests that tax credit programs should be supported by legislatures with limited or temporary funding as tax credits and abatements require considerable funding. In practice, the project receives a certain amount of credit after certification with a green building certification system. Usually, the credit amount has a predefined limit supported by legislation. The provision of satisfactory financial resources are vital for the effective implementation of the tax abatement system in green building programs. Otherwise, negative financial impacts may occur. In this respect, Prum (2009) provides an example from Nevada state's incentive program, where a hastily prepared legislation without a proper financial impact analysis and with too much room for interpretation caused a financial crisis to occur.

\section{Fee reduction and waivers}

Fee reduction and waivers include reductions or waivers from the fees required by municipalities for plan reviews and building permits. The aim is to offset additional costs (e.g. registration) associated with qualification with a certificate. The level of reduction in fees is often identified according to the level of certification achieved. It is also common that applications for expedited permitting and fee reduction are submitted together. Several barriers faced during the implementation of fee reduction and waivers are reported in literature. Firstly, there is a necessity of qualified staff for the assessment, qualification of applicants and the monitoring of conformance. Secondly, owing to its financial nature, these types of incentives require that local governments find the additional financial resources necessary for their implementation. Circo (2009) points out that one solution for such financial difficulties could be cost shifting by increasing the fees applied to traditional projects and in this way balancing the fiscal situation.

\section{Awards and Marketing Assistance}

Awards and marketing assistance include the provision of both financial and marketing promotions by local governments for developments that meet prespecified green building criteria. Green building awards organized 
by municipalities generally require a financial investment by the city. While the main aim is to increase the marketability of green developments and thus owner profits, secondary benefits such as increased public awareness also helps awards and marketing assistance to become more popular. The most common instruments of marketing assistance for green buildings cover public signages, including the project on cities' green building web pages and the use of other media such as press releases and broadcasting.

\section{METHOD}

Once the most common incentive models were identified and categorized through an extensive literature review, case studies were conducted with local governments. The adaptibility of incentive models to the developing countries was assessed through feedback from local governments as they form the most active part of the system. Theaker and Cole (2001) suggest that local governments are best placed and equipped to implement policies for the development of sustainable building market. The authors provide several factors for the reinforcement of this argument. First, local governments possess required organizational capabilities in creating and adopting development plans and building construction standards such as building codes. Second, green building initiatives and programs by local governments act as a stimulating mechanism for larger governments and a bottom-up approach could be adopted. The third aspect is associated with the local nature of sustainability; that is, the day-to-day experience of local governments could provide a more precise picture of local conditions and public concerns.

The local government cases to be analyzed were selected based on the knowledge and experience across green buildings and on the willingness of directorates to participate in the study. Five local authorities have expressed interest in the study and directors from relevant departments were interviewed. In some municipalities, more than one director participated in interviews. The municipalities had all different characteristics in terms of projects undertaken, land use and historical characteristics of the region. This approach allowed for the reflection of diverse experiences on the delivery and management of projects across a wide range of subsectors. Table 1 outlines the key characteristics of the municipalities participated in the study.

The focus of the research was to find out how local governments perceive economic incentives and how their implementation may influence the way in which processes are carried out. As the theme is largely unexplored both in theory and application, a qualitative study using a semi-structured interview technique was adopted in collecting the necessary data. The interviews were made and recorded by the second author. Each interview lasted about 2 to 2.5 hours. During the interviews, selected municipality interviewees were informed about incentive models and directed to give their views about opportunities and potential application risks. While some questions focused on obtaining the perspectives of interviewees on specific incentive models, others were designed to reflect the possible obstacles that could be faced during implementation, thus to explore the availability of resources that could be exploited in the face of challenges. 


\begin{tabular}{|c|c|c|}
\hline \multirow{10}{*}{$\begin{array}{l}\text { CASE } \\
\text { STUDY A }\end{array}$} & Description & Located in the European side of Istanbul. \\
\hline & & Existing built environment consists of low-rise industrial and residential \\
\hline & & properties, however there are ongoing efforts to move the polluting industries \\
\hline & & out of the region. \\
\hline & & Remarkable urban renewal projects have started to be undertaken with a \\
\hline & & particular focus on transforming low rise illegal settlement into high rise \\
\hline & & residential developments. \\
\hline & & $\begin{array}{l}\text { The authorities emphasize the cultural, touristic and commercial potential in } \\
\text { the region. }\end{array}$ \\
\hline & Population & $200000-300000$ \\
\hline & $\begin{array}{l}\text { Interviewed } \\
\text { department }\end{array}$ & Department of Reconstruction and Town Planning \\
\hline \multirow{7}{*}{$\begin{array}{l}\text { CASE } \\
\text { STUDY B }\end{array}$} & Description & District consists of mainly mid-rise residential and commercial buildings. \\
\hline & & Remarkable urban renewal projects have started to be undertaken with a \\
\hline & & particular focus on transforming low rise residential properties into high rise \\
\hline & & residential developments. \\
\hline & & Open to new development \\
\hline & Population & $400000-500000$ \\
\hline & $\begin{array}{l}\text { Interviewed } \\
\text { department }\end{array}$ & Strategy Development Department \\
\hline \multirow{6}{*}{$\begin{array}{l}\text { CASE } \\
\text { STUDY C }\end{array}$} & Description & $\begin{array}{l}\text { District known as the cultural center of the City with a wide range of arts and } \\
\text { cultural activities. }\end{array}$ \\
\hline & & Existing built environment consists of largely mid rise commercial and \\
\hline & & residential developments. \\
\hline & & High density land use is permitted in the new tourism development areas. \\
\hline & Population & $200000-300000$ \\
\hline & $\begin{array}{l}\text { Interviewed } \\
\text { department }\end{array}$ & Licence Bureau \\
\hline \multirow{6}{*}{$\begin{array}{l}\text { CASE } \\
\text { STUDY D }\end{array}$} & Description & Existing built environment consists of mid rise residential properties. \\
\hline & & The municipality is already experienced in green buildings. \\
\hline & & There are planned and ongoing urban renewal projects that aim to transform \\
\hline & & low quality housing into high rise earthquake resistant residential projects. \\
\hline & Population & $500000-600000$ \\
\hline & $\begin{array}{l}\text { Interviewed } \\
\text { department }\end{array}$ & Project Coordination Bureau and Environmental Protection Department. \\
\hline \multirow{7}{*}{$\begin{array}{l}\text { CASE } \\
\text { STUDY E }\end{array}$} & Description & There are ongoing plans to transform the city into a metropolitan municipality \\
\hline & & The majority of existing built environment is characterized by low quality \\
\hline & & housing developments. \\
\hline & & New residential developments within the scope of Urban Renewal Project have \\
\hline & & been started. \\
\hline & Population & $>1000000$ \\
\hline & $\begin{array}{l}\text { Interviewed } \\
\text { department }\end{array}$ & Department of Reconstruction and Town Planning \\
\hline
\end{tabular}

FINDINGS AND DISCUSSION

\section{Expedited Review /Permitting Processes}

Although expedited review and permitting was viewed as a simple and easily applicable system for the majority of case study participants, the interviewees from case A and C were sceptical about the efficiency of such 
incentive mechanism and argued that the review, permit and licencing processes in their municipality are already completed in reasonable times. It has been stated that the extent to which the processes could be accelerated is very limited. Therefore, in particular, case A was sceptical about the effectiveness of the expedited review/permitting option in encouraging developers for building green in their region. The interviewee could foresee the necessity of technical staff training for the implementation of this new system, and cited an example where the Ministry of Environment and Urban Planning opened courses in order to train and accredite asessors for the recently established Energy Performance Certificate System (Bep-Tr), implemented under the Energy Performance of Buildings Regulation. Bep-Tr includes a calculation methodology and a related software which can only be used by accredited professionals. The system outputs are then submitted to local government database and approved. The interviewee felt that at the initial phases of implementation, the most efficient way to manage the specialization required by the complex assessment process was to transfer the responsibility to accredited professionals similar to the Bep-Tr model.

When the challenges associated with the lack of coordination between public institutions were mentioned, the interviewee from Case A suggested that the establishment of a common information platform coupled with the e-signature system could be useful in avoiding the possible conflicts and miscommunication between different institutions. In this regard, an example from Istanbul Water and Sewerage Administration (ISKI) was provided, where a specialized platform including an e-signature system is established for internal correspondance. Due to the successful implementation of this platform, the interviewee noted that a similar model could be adopted in the creation of a common environment for the public institutions that are involved in review and permitting processes.

Case B, D and E were among the local authorities for which the implementation of the expedited review and permitting processes was welcomed with enthusiasm. All stated that it was possible to shorten the current durations for permit and review. As far as the need for additional and/or trained staff is concerned, the interviewee from Case B felt that the establishment of a new, specialized department was the key for the successful implementation of expedited review and permitting incentive. It was suggested that the Ministry of Environment and Urban Planning should take up the responsibility of providing trainings for permitting staff. Previous experience from several trainings provided by the Ministry was perceived to be very effective and the respondent emphasized that a similar program could be adopted for the training of staff required for expedited review and permitting processes.

While all of the three local authorities in this group provided positive feedback about the expedited review and permitting incentive, there was a disagreement about the outsourcing of reviews to the private sector. Case $B$ argued that recourse to the private sector for reviews was completely inappropriate. On the contrary, the interviewee from Case E commented that the private sector was the true authority in training the staff and in pursuing the complex processes associated with the assessment of green building features.

A consensus was reached on the possibility of the occurance of coordination problems between public institutions during the implementation of expedited reviews. Case B mentioned problems from 
previous experiences and emphasized the conflicts in bilateral relations between institutions and even between high-level administrators. Case E on the other hand described the lack of coordination and communication as the most considerable risk in the implementation of the expedited review/ permitting incentive. The interviewee also stated that confusion on local and general regulations that may occur at the initial stages may further complicate the implementation.

\section{Density and Height Bonuses}

The majority of the interviewees except Case B found density and height bonus incentive favourable but all stated that density and height bonuses should be used with caution. The interviewee from Case A stated that in Istanbul there are mainly attached buildings and floor area ratios are around 4-5 and even in some regions such as the interviewee's region, it amounts to 5-6. Taking into account the already high population densities, density \& height bonuses seemed inapplicable. Nevertheless, the interviewee from Case A commented that 'if parcels reach a certain size, it could be possible to expand FAR rates by $5 \%, 10 \%$ or $15 \%$ in our region'.

The interviewee from Case $\mathrm{E}$ approached density and height Bonuses in a similar fashion by stating that 'Density and Height bonuses could be an attractive incentive model for us but there are some concerns about zoning plans prepared for the city'. He mentioned that Turkey has a building stock mainly consisted by attached buildings and Urban Renewal Law (Law No: 6306) should be rearranged and attached building city blocks should be converted to appropriate city blocks for the development of sustainable green building markets.

The interviewee from Case B found density and height bonuses completely inapplicable due to environmental reasons. He commented that "the reduction of real green for incentivizing green building is a very wrong move. However, politicians and municipal councils may find this mechanism attractive for political reasons"

The interviewee from Case C and Case D state that density and height bonuses are suitable for their Municipality. Recently the municipality from Case $C$ provided height bonuses in some districts based on detailed soil investigation reports. However, as there are protected historical areas in almost every street, the council of monuments intervene the situation and use their authority in defining height limits.

\section{Tax Abatements and Credits}

In current conditions, tax abatements and credits are not yet applicable for the majority of the interviewees. Case A, B and C stated that the implementation of tax abatements did not seem possible because the income that the municipality recieves from public is already limited and a further could cause imbalance in their fiscal situations. Case D pointed out a legislative problem regarding the use of tax abatements and credits. Local municipalities do not have the authority to change tax ratios. If the Ministry of Finance decides to take decision and prepare the legislative background, the municipality has to apply it. Nevertheless, tax credits and abatements still did not appear as a possible solution in current conditions. The interviewee from Case $\mathrm{E}$ also stated that there will be budgetary deficit by abatements. In this regard he stated that "covering the deficit by increasing the tax for traditional buildings is not a feasable option. In this point, to tolerate the lack of budget may be possible by; revenue increasing 
by green building applications/technologies, resource savings and reduce foreign dependency etc."

On the other hand, ease of payment (e.g. the extension of the repayment period) was welcomed by all of the interviewees. Urban renewal model was mentioned by case A, for which there are longterm and low-interest loan opportunities for buildings that has received acceptance to be included in the urban renewal project.

\section{Fee Reduction and Waivers}

The interviewee from Case A stated that the application of a $100 \%$ fee waiver was possible for Land Registry Office processes, zoning status, grade elevation and road condition document applications, getting empty land document or burned/demolished form, license application, static and mechanical project control and licence fee payment. However, for static, mechanical, electrical, geological and map projects and building audit firm's control and file preparation processes, fee reduction did seem applicable.

The interviewee from Case C stated that a 100\% fee waiver was possible for grade elevation application, getting empty land document of demolished form and licence fee payment. However, according to the interviewee, this incentive model did not seem suitable for other processes. Case E commented that a $100 \%$ fee waiver was possible for only licence fee payment. According to the interviewees from Case B and Case D, fee reduction/ waiver model is not suitable due to financial reasons mentioned before.

\section{Awards}

According to the interviewees from Case A and Case C, awards are easily applicable incentive models. As far as the creation of financial resources for the application of this model is concerned, the interviewees came up with different ideas. For example while Case $A$ and $C$ focused on property taxes for the creation of financial resources, Case E offered the inclusion of sponsors. Case D is already an experienced municipality which has organized sustainable urban project competitions in different areas. Resource for awards are being raised from property and environmental cleaning taxes, land sales and from rental revenues of the municipality.

Only the interviewee from Case B felt that the application of awards was difficult as cash prizes may challenge municipality's resources. When the possibility of allocating a portion of property tax for this reason was asked, the interviewee stated that this approach will not be welcomed by some groups due to political reasons.

\section{Marketing Assistance}

Marketing assistance was another favourable incentive option for the interviewees. All of the interviewees from case studies could easily provide several resources that can be used in the application of marketing assistance. Marketing channels like website of the municipality, local newspapers and the use of billboards were suggested by all interviewees. Additionally, Case $C$ stated that marketing assistance for green buildings could also be provided by municipality journals.

As far as the use of the resources of the metropolitan municipality is concerned, the interviewees had distinct opinions. Case A stated that metropolitan municipality could also generate competitions for green 
projects for a more effective promotion. Case $\mathrm{C}$ commented that the coordination with metropolitan municipality seemed possible in case there are considerable projects. Case B and D stated that the use of the opportunities of metropolitan municipality is not welcomed by county municipality because of political reasons.

\section{CONCLUSIONS}

The perceived high cost of green buildings is a particular concern for developers. Thus, for the dissemination of green buildings, the starting point should be the provision of incentives that will offset developers' costs. The main objective of this research was to evaluate the applicability of current incentive models for countries that are in the early phases of transition to green buildings and to identify the difficulties in their implementation. This has been achieved through a better understanding of the local authorities' perspectives on the most common green building incentive mechanisms used by other countries.

For local governments, the applicability of each incentive model appear to have some advantages and drawbacks. Results reveal that marketing assistance is the easiest and most preferable incentive mechanism that does not require a structural change and that could be applied at no cost as the municipalities already have the resources necessary for its implementation. While tax abatement is not yet applicable due to financial reasons and regulatory structure, ease of payment in green building taxes appears to be a favourable option. Respondents could easily count several resource opportunities for awards, thus this incentive model is also one of the most easily applicable incentive mechanisms. However, there were very different views on the implementation of expedited reviews. The most critical risks in this regard appear to be the lack of coordination between governmental institutions involved in permits and the possible conflicts that may occur between local and general regulations. The problems associated with the overlapping of regulations and laws already exist; thus increased challenges are expected with the introduction of an additional governing structure. The problem regarding the lack of qualified staff were also mentioned. However, previous experience in most of the municipalities interviewed prove that this issue can easily be resolved through trainings by central government and the inclusion of private sector. There was a high degree of consensus among respondents that the establishment of a dedicated department with clear roles and responsibilities is the key for the effective implementation of expedited reviews and permits. This approach may further help in sorting out the 'proof of compliance' problem, through a system that allocates the responsibilities regarding the adoption of sanction models (such as bonds, letters of credit or penalty in the form of certificate of occupancy) to the dedicated departments. The incentive model about which the interviewees raised the most serious concerns was the density and height bonuses. In this regard, the applicability of density and height bonus incentive in historical zones and controversies surrounding the idea of reducing real green for the sake of incentivizing the green building market were identified as obstacles that are very hard to overcome.

The results of this study may be beneficial for central and local governments that plan to adopt green building incentive models. In particular, the findings regarding the need for a clear legislative system for green buildings should be interpreted with caution. Local authorities 
bridge the gap between developers and government, so their views should be evaluated carefully in the development of an effective regulative system. In this concept, more emphasis should be given to documenting the experience of advanced countries in green building regulatory structures and the coordination models between departments. Once the main guidelines for an appropriate organizational and legislative basis for incentive mechanisms are established, further research should focus on obtaining the perspectives of developers.

\section{REFERENCES}

ANG, S.L., WILKINSON, S.J. (2008) Is the Social Agenda Driving Sustainable Property Development in Melbourne, Australia?, Property Management 26 (5) 331-343.

ANTONIADES, H. (2011) The Application of Taxation Benefits and Incentives for Green Buildings. [http://soac.fbe.unsw.edu.au] Access Date (20.02.2014).

BARTLETT, E., HOWARD, N. (2000) Informing the Decision-Makers on the Cost and Value of Green Building, Building Research \& Information 28 (5/6) 315-24.

BON, R., HUTCHINSON, K. (2000) Sustainable Construction: Some Economic Challenges, Building Research \& Information 28 (5/6) 301-4.

BORDASS, W. (2000) Cost and Value: Fact and Fiction, Building Research $\mathcal{E}$ Information 28 (5/6) 338-352.

CARTER, E. (2006) Making Money From Sustainable Homes: A Developer's Guide, Ascot, UK: CIOB publications.

CIRCO, J.C. (2008) Using Mandates and Incentives to Promote Sustainable Construction and Green Building Projects in the Private Sector: A Call for More State Land Use Policy İnitiatives, Penn State Law Review (112) 1-43.

CIRCO, J.C. (2009) Should Owners and Developers of Low-Performance Buildings Pay Impact or Mitigation Fees to Finance Green Building Incentive Programs and Other Sustainable Development Initiatives?, William \& Mary Environmental Law and Policy Review (34) 55-98.

COLE, R.J. (2011) Motivating Stakeholders to Deliver Environmental Change, Building Research \& Information 39 (5) 431-35.

DU PLESSIS, C., COLE, R.J. (2011) Motivating Change: Shifting the Paradigm, Building Research E Information 39 (5) 436-49.

ELLISON, L., SAYCE, S., SMITH, J. (2007) Socially Responsible Property Investment: Quantifying the Relationship Between Sustainability and Investment Property Worth, Journal of Property Research 24 (3) 191219.

FEIGE, A., WALLBAUM, H., KRANK, S. (2011) Harnessing Stakeholder Motivation: Towards a Swiss Sustainable Building Sector, Building Research E Information 39 (5) 504-17.

FUERST, F., MCALLISTER, P. (2011) Green Noise or Green Value? Measuring the Effects of Environmental Certification on Office Values, Real Estate Economics 39 (1) 45-69. 
GLUCH, P., GUSTAFSSON, M., THUVANDER, L., BAUMANN, H. (2013) Charting Corporate Greening: Environmental Management Trends in Sweden, Building Research E Information 42 (3) 318-29.

HAKKINEN, T., BELLONI, K. (2011) Barriers and Drivers for Sustainable Building, Building Research E Information 39 (3) 239-255.

HOFFMAN, A.J., HENN, R. (2008) Overcoming the Social and Psychological Barriers to Green Building, Organisation and Environment 21(4) 390-419.

JAFFEE, A.B., PETERSON, S.R., PORTNEY, P.R., STAVINS, N.R. (1995) Environmental Regulation and Competitiveness of us Manufacturing: What Does the Evidence Tell Us, Journal of Economic Literature 33 (1) 132-63.

KAATZ, E., ROOT, D.S., BOWEN, P.A. (2005) Broadening Project Participation Through a Modified Building Sustainability Assessment, Building Research \& Information 33 (5) 441-54.

KAATZ, E., ROOT, D.S., BOWEN, P.A., HILL, R.C. (2005) Advancing Key Outcomes of Sustainability Building Assessment, Building Research \& Information 34 (4) 308-20.

LÜTZKENDORF, T., FAN, W., LORENZ, D. (2011) Engaging Financial Stakeholders: Opportunities for a Sustainable Built Environment, Building Research E Information 39 (5) 483-503.

MEIJER, F., ITARD, L., SUNIKKA-BLANK, M. (2009) Comparing European Residential Building Stocks: Performance, Renovation and Policy Opportunities, Building Research \& Information 37 (5/6) 533-51.

MILLER, N., SPIVEY, J., FLORANCE, A. (2008) Does Green Pay Off?, Journal of Real Estate Portfolio Management 14 (4) 385-99.

OSMANI, M., O'REILLY, A. (2009) Feasibility of Zero Carbon Homes in England by 2016: A House Builder's Perspective, Building and Environment, (44) 1917-24.

OXFORD BUSINESS GROUP (2012) Planned Development: Urban Renewal Programmes Plus Major Infrastructure Projects Equal Significant Opportunities for Investment. [http://www.oxfordbusinessgroup.com] Access Date (22.12.2013).

PANAYOTOU, T. (1994) Economic Instruments for Environmental Management and Sustainable Development, Environmental Economics Series Publication no.16, United Nations Environment Programme (UNEP), Environment and Economics Unit (EEU).

PETT, J., GUERTLER, P., HUGH, M., SMITH, W. (2004) Invisible Property Investment: 'Asset Value Implications of Low Energy Offices, Association for the Conservation of Energy, London.

PIPPIN, A. (2009) Survey of Local Government Green Building Incentive Programs for Private Developments, Land Use Clinic Paper 2.

PITT, M., TUCKER, M., RILEY, M., LONGDEN, J. (2009) Towards Sustainable Construction: Promotion and Best Practices, Construction Innovation: Information, Process, Management 9 (2) 201-224.

PRUM, D. (2009) Creating State Incentives for Commercial Green Buildings: Did the Nevada Experience Set an Example or Alter the 
Approach of Other Jurisdictions?, WM. \& Mary Envtl. L. \& Pol'y Rev. (34) $171-207$.

RETZLAFF, R. (2009) The use of LEED in Planning and Development Regulation: An Exploratory Analysis, Journal of Planning Education and Research 29 (1) 67-77.

ROYAL INSTITUTE OF CHARTERED SURVEYORS - RICS (2005) Green Value: Green Buildings, Growing Assets, RICS, London.

SAYCE, S., ELLISON, L., PARNELL, P. (2007) Understanding Investment Drivers for UK Sustainable Property, Building Research \& Information 35 (6) 629-43.

SODAGAR, B., FIELDSON, R. (2008) Towards A Sustainable Construction Practice. Construction Information Quarterly 10 (3) 101-8.

THEAKER, I.G., COLE, R.J. (2001) The Role of Local Governments in Fostering 'Green' Buildings: A Case Study, Building Research $\mathcal{E}$ Information 29 (5) 394-408.

UNITED NATIONS ENVIRONMENT PROGRAMME (UNEP), Sustainable Building and Construction Initiative -SBCI (2007) Buildings and Climate Change: Status, Challenge and Opportunities, UNEP, Paris.

UNITED NATIONS ENVIRONMENT PROGRAMME (UNEP), Sustainable Building and Construction Initiative (SBCI) (2009) Buildings and Climate Change: Summary for decision-makers, UNEP DTIE, Paris.

US EPA REGION 5, NEMW, DELTA INSTITUTE (2008) Removing Market Barriers to Green Development: Principles and action projects to promote widespread adoption of green development practice, US Environmental Protection Agency, Chicago.

U.S. GREEN BUILDING COUNCIL -USGBC (2010) Green Building Incentive Strategies. [http://www.slocounty.ca.gov] Access Date (21.11.2013).

WALLBAUM, H., SILVA, L., DU PLESSIS, C., COLE, R., HOBALLAH, A., KRANK, S. (2010) Motivating Stakeholders to Deliver Change, 3rd Holcim Forum for Sustainable Construction: "Re-inventing construction" workshop-specific topic: "Stimulate stakeholders-with incentives to implementation" (14-16 April 2010) Holcim Foundation, Mexico City.

WHYTE, J., SEXTON, M. (2011) Motivations for İnnovation in the Built Environment: New Directions for Research, Building Research $\mathcal{E}$ Information 39 (5) 473-482.

WILEY, J., BENEFIELD, J., JOHNSON, K. (2010) Green Design and the Market for Commercial Office Space, The Journal of Real Estate Finance and Economics 41 (2) 228-43.

YILDIRIM, S..U. (2014) The Applicability of Current Green Building Incentive Models to the Turkish Property Market, Unpublished Master's Thesis, Building Engineering Division, Mimar Sinan Fine Arts University, Istanbul.

ZHANG, X., PLATTEN A., SHEN L. (2011) Green Property Development Practice in China: Costs and Barriers, Building and Environment (46) 2153-2160. 
Alındı: 19.03.2015; Son Metin: 01.10.2015

Anahtar Sözcükler: inşaat sektörü; yeşil binalar; teşvikler; sürdürülebilir yapılar; yerel yönetimler

\section{YEŞİL BİNALARIN YAYGINLAŞTIRILMASINDA TEŞVIKLERİN KULLANILMASI}

Çalışmada dünyada yaygın olarak kullanılan yeşil bina teşvik sistemlerinin uygulanabilirliği, Türkiye örneği üzerinde değerlendirilmiştir. Yerel yönetimlerle yapılan görüşmeler sonucunda teşvik sistemlerinin etkin bir şekilde uygulanabilmesi için gerekli olan şartlar, karşılaşılabilecek zorluklar ve fırsatlar belirlenmiş ve değerlendirilmiştir. Sonuçlar, Türkiye örneğinde düşük maliyetli veya maliyete gereksinim duyulmayan grupta en elverişli teşviklerin pazarlama yardımı ve hızlandırılmış inceleme/izin olduğunu göstermektedir. Gelişmekte olan ülkelerde yüksek maliyet içeren mali teşviklerin uygulanmasına yönelik önyargıya karşın, bu grupta ödül ve harçların düşürülmesi ile ilgili teşviklerin uygulanabilir olduğu ortaya çıkmıştır. Yapılan görüşmelerde hakkında en çok endişelerin dile getirildiği teşvikler emsal ve yükseklik artırımına imkan veren teşvik grubudur. Bu tip teşviklerin doğurabileceği sorunlar özellikle tarihi bölgelerde görev yapan yerel yönetimler tarafından vurgulanmıştır. Her ne kadar birimler arası örgütsel sorunların çözümü için öneriler getirilebilse de, kamu kuruluşları arasındaki eşgüdüm eksiklikleri ve özellikle yerel ve genel mevzuat arasındaki tutarsızlıklar çözülmesi gereken en önemli sorun alanları olarak görülmektedir.

SELİN GÜNDEŞ; B.Arch, M.Sc, PhD.

Currently works as an Associate Professor at Mimar Sinan Fine Arts University. Holds an MSc in Construction Economics and Management from University College London, Bartlett School of Built Environment, and $\mathrm{PhD}$ in Construction Management from Politecnico di Milano, Dipartimento di Scienza e Tecnologie dell'Ambiente Costruito. sgundes@libero.it.

ŞİAR UMUT YILDIRIM; B.Eng, M.Sc.

Holds an MSc. degree in Construction Management Programme from Mimar Sinan Fine Arts University (2014). Currently a PhD candidate at İstanbul University. Worked on the İkitelli Integrated Health Campus Project as a project management engineer. siarumutyildirim@ gmail.com. 